\title{
ANNOUNCEMENT OF PRIZE AWARDS
}

$\mathrm{ON}_{\mathrm{N}}$ the completion of each volume of the fournal the Committee may award one or more prizes for meritorious contributions from 'junior' members of the Society.

In connexion with Vol. I 6 the Committee has awarded prizes to the authors of the following articles:

'The Impact of National Insurance Act, I959 on Private Pension Schemes' by T. Hugh BeEch.

'The Extra Premium for a Premium Rebate Benefit in Recurrent Single Premium Group Life Assurance' by P. M. Madders.

The conditions of the award are as follows:

The award or awards shall be made after consideration of the contributions published in each volume of the fournal, whether by way of reprints of opening remarks made at sessional meetings or as original contributions to the fournal. Awards will be restricted to members of the Society, who were not qualified at the date of the sessional meeting at which the remarks in question were made or at the date when the contribution first reached the hands of the Editors as the case may be, and to those who qualified during the three years preceding that date. The expression 'qualified' shall include Fellows of the Institute or the Faculty of Actuaries or those in possession of a qualification recognized by the Committee as being of equivalent standard. 